temporary stars we have grounds for looking to the latter, while in the case of stars of the Algol group we have reasons for looking to the former, as a more or less probable cause of the changes we observe. While in $\beta$ Lyra we see that physical changes apparently accompany, if they are not connected with the cause of, the light variation. Is it to geometric or to chemico-physical causes that we are to look as the key to the explanation of the ph nomena in other groups, say of the large group of Class II.? A few considerations will show the grave difficulties we have to meet. A difference of from five to seven magnitudes between the points touched by the star at maximum and minimum is to be found in the case of many members of Class II. Now, taking the magnitude scale at present generally adopted, having a light-ratio of $2.5 \mathrm{I} 2$, a range of five magnitudes would correspond to a difference of light-intensity in the proportion of roo to 1 , while if the range is extended to scven magnitudes, the star's light-intensity at maximum would bear to its lightintensity at minimum a ratio of 630 to 1 . These wide differences of intensity of radiation are sufficiently startling if they are supposed to occur only once in a while, as in the case of the temporary stars. What are we to say of them if we are to suppose them to occur over and over and over again, in periods of from 150 to 600 days? The subject was discussed in these columns some few years ago, and the difficulties presented were folt to be so serious as to make it hard to accept a theory of this kind as offering a probable explanation of the facts if these stars are to be regarded as suns in the usual sense of the term, though less difficulty might be felt if we could look on them, not as suns in our sense at all, but as small bodies. In this case they would be relatively near to ws, and would have a measurable parallax. An inquiry in this direction might prove fruitful. As compared with this theory, the theory that the changes of light may be supposed due to periodic obscurations by bodics or groups of bodies revolving around the variable, presents less formidable objections, though it has, of course, difficulties of its own. A few months ago one of our first authorities on the subject pemned the words: "No theory has yet been advanced that will account satisfactorily for the ordinary phenomena of variable stars." It is possible that we must look forward to a future of more or less lengthened patient research before theoretic views can be announced which shall be anything much better than "guesses at truth."

It is, then, to further work that we must look for further progress, and the recent discoveries in regard to $\beta$ Lyræ indicate one direction at least in which research should be made. Is it not possible that some valuable results might be obtained if the spectra of a selected list of variable stars were to be carcfully studicd with one of our largest telescopes - the several spectroscopic results being co-ordinated with the corresponding position of the star in its light-curve as fixed by a careful determination of its magnitude? In the discovery of new variables, the determination of their periods and range of variation, and of the general characteristics of their light-curves, good work may be done with instruments of very moderate dimensions; but for all but the brighter stars the spectra arc too faint to be adequately treated but by instruments of the largest size.

Whether by this means any satislactory results should be obtained or no, it is evident that in the study of variable stars a point has been reached whence, in order to secure any further advance, it seems needful by some means or other to endeavour to take a new departure.

\section{THE LATE EARL OF SELKIRK}

C $\mathrm{N}$ Saturday, April 11, 1885, Dunbar James Douglas, sixth and last Larl of Selkirk died, after a short llness, at St. Mary's Isle, Kircudbright; had he lived till the and of the month he would have completed his seventy-sixth year. His death, though it occurred at a ripe age, has proved a sudden and unexpected blow to those who hoped that many years of life might yet remain to one upon whose spare and still vigorous frame, age had as yet apparently made but little impression, and whose mental and physical energy alike gave promise of a still prolonged period of utility. Those who so recently saw him in even more than his wonted health now sadly realise the fact that he has succumbed, like many others, to the evil influences of the treacherous and bitter east winds which for some time swept over our islands, and terminated his valuable life after a short illness of but three weeks. How much he is regretted, how sorely he will be missed, it is impossible to say; for the removal of one so gifted and so grood is an irreparable loss, which will be felt more and more as time progresses, wherever the genial infuence of his life and example had been felt

Elsewhere have been described his ancient lineage, his connection with various great families of historic fame, his political opinions, his public life, the high offices he filled in the State and in his county, the charms of personal character which marked his whole life ; his edu. cation at Eton, his success at Oxford, his travels and explorations in almost every quarter of the globe ; the rich harvest of experience he so assiduously collected and so carefully and accurately remembered ; his thoughtful, unselfish nature, so loyal, so consideratc of others, especially of the weak; so firm in assertion of all that he believed to be right, so excellent in all relations of public, private, and domestic life, so true a friend, so mindful of all who ever did or tried to do him the slightest service - all this may some day be told again in detail, but need not be dwelt on here in this brief notice, which contemplates rather the side of his nature which turned towards science and took so keen an interest in its progress and welfare, he himself being no mean contributor to its annals. Those who, like the writer, have had the privilege of intimate association with him, in the field, on the moor, in social life, and by the evening fireside, and have listened to his instructive conversation on many subjects connected with natural science, history, geography and biography, and have felt the satisfaction which arises from communion with one whose wisdom and experience seldom erred, who enunciated no crude theory, made no hasty generalisation on imperfect or insufficient data, and whose judgment was tempered, calm and reasonible in all matters submitted to it for decision, must feel that, by his death, science too has sustained a serious loss.

Lord Selkirk's great erudition and knowledge of men and nature were not derived merely from books. He was, indeed, a great reader, whose memory retained with extraordinary tenacity all the details even to minute particulars of that which he read: his vast stores of information were the result of much travel and study of physical science. Few, indeed, had travelled so far, or seen so much, or with such intelligent appreciation of what they did observe.

His mind was of a truly scientific mould, and accepted nothing on insufficient or imperfect evidence; his interest in all that was calculated to extend the limits of science was unbounded; but of all its dcpartments, geology seemed to attract him most : he was a Fellow of the Geological Society, a frequent attendant at its meetings, and a contributor to its proceedings. One paper on "Sea-water Level Marks on the Coast of Sweden," vead before the Society in 1867 , was of much interest, and shows how closely he had studied that important subject. He was also a Fellow of the Royal Society, and took much interest in its proceedings, but deafness, which affected him early in life and increased with age, prevented him from taking an active part in the discussions of the learned societies, or in the debates in the House of Lords, and to a certain extent, therefore, disqualified him 
from sharing in, though it in no way diminished the keen interest he felt in their deliberations.

The library in his beautiful and ancient home contained many works on science, literature, and art, but the great storehouse of knowledge was his own brain, and from this he was ever delighted to contribute for the instruction and amusement of his friends. All this, alas, has come to an end; the venerated form will no longer be seen where it was known so well, in the Isle, or in its picturesque surroundings overlooking the sea, but his memory will long be everywhere preserved in grateful recollection by his friends and countrymen.

J. F.

\section{ROR AIMA}

$\mathrm{B}^{\mathrm{Y}}$ the kindness of Sir Joseph Hooker we ar able to give some illustrations relating to Roraima taken by $\mathrm{Mr}$. Im Thurn during his recent successful expedition (aided by funds supplied by the British Association and Royal Geographical Society) to the top of the previously unscaled mountain. The following extracts from the paper read on Monday at the Royal Geographical Society, by Mr. H. J. Perkin, who accompanied Mr. In Thurn, will give some idea of the work and results of the expedition :-

The Ist of December, our first day in Brazilian territory, we camped to the south-west of, and quite close to Waetipu, a splendid mountain towering above the general level of the table-land some 300 s or 4000 feet, with bold, sharp outlines ending in a well-defined peak, on its south side free from forest, the savannah continuing quite up to its summit, though densely wooded on its north-northeast and north-west.

From a lofty range of hills some 3600 feet high we had a splendid view of Waetipu, Roraima, Kukenam, Marima, and two small mountains near Waetipu, named Hormi and Mucureepa ; the curious square, flat tops of Roraima and Kukenam, with their dark, precipitous cliffs, adding a grand and peculiar effect to the whole landscape. On December 2 we arrived at Toroikire or Ipelemonta, an Arecuna vill tge of four houses situated on the left bank of the Arapu river.

The view from here is magnificent, as the village is placed just in front of Roraima, giving a sight also of Kukenam; it is situated on a high hill 3751 feet above sea-level, but is dwarfed by the gigantic walls of rock near it, Roraima being about four, and Kukenam about three miles from it. Each mountain seems like a huge impregnable fortress, built on a mountain-top 7000 feet high, with walls from 1200 to 1800 feet in height.

The portion of Roraima facing Teroota is four miles long, and of Kukenam about the same. In wet weather their summits are wrapped in dark clouds, and after the rain is over and the clouds have dispersed the water can be seen casting itself over the cliffs in splendid falls that only by being seen can be at all imagined. At a distance of four to five miles they look like delicate white threads against the dark background of sandstone rock.

The two mountains are separated by a wide gorge, and in this clouds of dense white mist accumulate, and gradually creeping up as the day advances, enshroud their summits something after the manner of the "table-cloth" of Table Mountain.

The chief difficulty Mr. Im Thurn apprehended was from the dampness of the spot, as he feared he would be unable to dry the sheets of botanical paper used to preserve the specimens of plants he obtained, but by means of a large fire kept burning night and day this was easily accomplished.

Whilst on this first visit of ours to the upper portion of Roraima we saw on the face of the cliff itself a Iedge of rock running up from the tree-covered portion of the highest sloping portion of the mountain to its summit ; it appeared to us extremely easy to climb, except in two places: the first where the bush that covered the ledge appeared to end suddenly, leaving the cliff bare and naked, and giving the ledge the appearance of being interrupted, and consequently impassable; and in the second place where a waterfall from the summit falls on the ledge and has cut a gap in it, so that there seems to be a deep, wide hole, which it would take great trouble to bridge over. But on the whole it seemed so easy to climb the mountain here that we concluded there must be some insuperable difficulty of which we were not aware, for other travellers who had visited the mountain had stayed near this ledge, though, except Mr. Whitely, none of them attempted it, most of them having had to turn back soon after their arrival, owing to want of provisions, which latter contingency $\mathrm{Mr}$. Im Thurn had particularly guarded against, and enabled us to stay some time and to make several excursions over the mountainsides.

The north-east and west sides of Roraima are forestcovered, but on the south and south-west it is for the most part devoid of trees until a height of 5890 feet is reached, and from here up to the cliff-face the slope becomes far more steep and is covered by a thick, dense undergrowth: there are very few large trees, and even they are small when compared with the giant vegetation of the forests we had passed through.

Teroota village lies, so to speak, at the foot of the mountain, though the cliff portion is about four miles distant. Between Teroota Hill and Roraima flows the Kukenam river, which rises in Kukenam Mountain and descends from the summit in a splendid fall of about 1300 feet.

From the Kukenam river Roraima on its south-western side slopes up at an angle of about $20^{\circ}$ to 4500 feet, and then at $30^{\circ}$ to the commencement of the forest-covered portion to 5890 feet; from here to the cliff-face the incline is $15^{\circ}$ steeper to about 7200 feet, and the remainder is cliff. At about 5600 feet we found a large piece of swampy ground filled with most exquisite varieties of orchids and ferns, and also the Uiricularia Humboldtii, which grows to greater perfection here than on the Kaieteur savannah. Here also we found the Heliamphora or pitcher-plant, whose cup-shaped leaves were full of water; it bears a delicate white flower without smell.

We returned the same day, December 5 , to Teroota, after our visit to Siedl.

We reascended the mountain on Sunday, December 7 , and built our houses, one for ourselves and one for the men, at an altitude of 5405 feet above sea-level, close to Siedl's hut.

On the Ioth, with Mr. Siedl, we went up a path cut by a Mr. Whitely in 1883 , to the face of the cliff, and on our way, at 6410 feet, found a lovely flowering plant, the Leiothamnus Elizabethe, of Schomburgk; it has deep carmine star-shaped flowers, with a white star centre, the points of which radiate down the petals. At 684I feet we rediscovered another exquisite flower, first found by Richard Schomburgk, an Utricularia, with a large deep crimson blossom. The plant grows on the branches of trees, and is about 2 to 3 inches in height; the bloom, when but, completely hides the stalk, and is about an inch and a quarter long, by half an inch wide; sometimes there are two flowers on the same plant, but usually only one. The appearance of one of these bright blossoms on the sombre tree-branches has a most peculiar effect, and one's admiration is divided between the brightress of the flower and the wonderful energy of the tiny plant that produces it. Pursuing our way we reached the cliff at I2 o'clock, nearly three hours from the start, the way being extremely rough and steep, over root and trunks of trees, and bare rocks: at times we could hear water running among the stones under our feet.

There are no trees of any very great size growing on 